\title{
In Search of Nella Larsen
}





\section{IN SEARCH OF NELLA LARSEN}

\section{A BIOGRAPHY OF THE COLOR LINE}

\section{GEORGE HUTCHINSON}

The Belknap Press of

Harvard University Press

Cambridge, Massachusetts

London, England 
Copyright $(\odot 2006$ by the President and Fellows of Harvard College All rights reserved

Printed in the United States of America

Designed by Dean Bornstein

Library of Congress Cataloging-in-Publication Data

Hutchinson, George.

In search of Nella Larsen : a biography of the color line / George Hutchinson.

p. cm.

Includes bibliographical references and index.

ISBN 0-674-02180-o (alk. paper)

1. Larsen, Nella. 2. Novelists, American - 2oth century-Biography.

3. African American novelists - Biography.

4. Harlem (New York, N. Y.) - Intellectual life-2oth century.

5. Harlem Renaissance. I. Title.

PS3523.A7225Z69 2006

$813^{\prime} .52-\mathrm{dc} 22 \quad 2005058129$ 
To James M. and Iris B. Hutchinson 
